\title{
Recurrent Implantation Failure What is beyond Endometrium and Embryo
}

\author{
Mohamed Elmahdy* \\ Department of Obstetrics and Gynecology, Alexanderia University, Egypt
}

Submission: February 21, 2017 ; Published: February 28, 2017

*Corresponding author: Mohamed Elmahdy, Department of Obstetrics and Gynecology, Alexanderia University, 13 Mostafa Hafez Street, El-Raml Station, Alexandria, Egypt, Tel: 03-4810081; Email: mahdy_moh@yahoo.com

\section{Opinion}

Recurrent implantation failure (RIF) is defined as failure to achieve pregnancy after transfer of embryos of good quality to implant in women under age of 40 following several in vitro fertilization (IVF) treatment cycles [1]. The failure to implant is due to declined endometrial receptivity, defective embryonic development and other factors like endometriosis, presence of hydrosalpinges [2]. Factors which might cause defective endometrial receptivity include uterine polyps, septa, leiomyomata and adhesions, thin endometrium and lack of good culture media for intra cytoplasmic sperm injection (ICSI) [3-5].

$35 \%$ of patients with RIF were found to have chronic endometritis (CE), confirming the importance of sampling the endometrial cavity in recurrent IVF-ET failures. This pathology may permanently alter the integrity or biochemical milieu within the endometrial cavity [6]. Office hysteroscopy is a useful diagnostic tool but should be complemented by an endometrial biopsy for the diagnosis of CE [7].

Recurrent ectopic pregnancy is one of the risk factors of RIF. The declined intrauterine implantation rate to some extent indicates an altered endometrium, which may play an important role in the pathogenesis of ectopic pregnancy [8].

Altered endometrial receptivity may be associated with immunological problems. Women with RM and RIF showed an increase of circulating proinflammatory cytokines, altered endometrial T lymphocytes subsets, and signs of endometrial ER stress [9].

Repeated implantation failure after IVF relates to diminished plasma volume along with increased uterine vascular resistance [10]. leukaemia inhibitory factor mRNA expression was significantly decreased in abnormal uterine cavities during the midsecretory phase, indicating that endometrial cavity defects are a possible cause of poor reproductive outcomes [11].
Inherited and acquired thrombophilias are encountered in many cases of RIF. Factor V HR2 was found to be associated with RIF and screening for the HR2 haplotype should be done in these patients [12]. Factor XII may be a good predictor, while there is no role to measure protein $\mathrm{C}$, protein $\mathrm{S}$, antithrombin III, or factor XIII. [13]. As regards acquired thrombophilia $9 \%$ of women with a history of recurrent implantation failure had more than one positive antiphospholipidantibodies [14].

Advanced maternal age is associated with a high frequency of chromosomal abnormalities. However, an even greater frequency of chromosomal abnormalities was seen in poor prognosis women with RIF regardless of age [15]. In women with recurrent implantation failure, two consecutive euploid IVF/PGD cycles is associated with a high ongoing pregnancy and implantation rate [16].

Recurrent implantation failure is a night mare for both the patients and the doctor. It needs a wide range of investigations and there is a debate about the lines of management. Till now the pregnancy rate after ICSI cycle in RIF patients still unsatisfactory.

\section{References}

1. Coughlan C, Ledger W, Wang Q, Liu F, Demirol A, et al. (2014) Recurrent implantation failure: definition and management. Reprod Biomed Online 28(1): 14-38.

2. Margalioth EJ, Ben-Chetrit A, Gal M, Eldar-Geva T (2006) Investigation and treatment of repeated implantation failure following IVF-ET. Hum Reprod 21(12): 3036-3043.

3. Demirol A, Gurgan T (2004) Effect of treatment of intrauterine pathologies with office hysteroscopy in patients with recurrent IVF failure. Reprod Biomed Online 8(5): 590-594.

4. Aoki VW, Wilcox AL, Peterson CM, Parker-Jones K, Hatasaka HH, et al. (2005) Comparison of four media types during 3-day human IVF embryo culture. Reprod Biomed Online 10(5): 600-606.

5. Shufaro Y, Simon A, Laufer N, Fatum M (2008) Thin unresponsive endometrium: a possible complication of surgical curettage compromising ART outcome. J Assist Reprod Genet 25(8): 421-425. 
6. Hartnett JM, Engmann L, Sanders MM, Maier D, Nulsen J, et al. (2005) The Role of Endometrial Biopsy in the Evaluation of Recurrent Implantation Failure. Fertility and Sterility 84(Suppl1): S272.

7. Bouet PE, El Hachem H, Monceau E, Gariépy G, Kadoch IJ, et al. (2016) Chronic endometritis in women with recurrent pregnancy loss and recurrent implantation failure: prevalence and role of office hysteroscopy and immunohistochemistry in diagnosis. Fertil Steril 105(1): 106-110.

8. Du T, Chen H, Qifeng Lyu, Kuang Y (2015) Recurrent ectopic pregnancy history is one of the risk factors of intrauterine implantation failure in women undergoing frozen-thawed embryo transfer cycles. Fertility and Sterility 104(3): e343.

9. Galgani M, Insabato L, Calì G, Della Gatta AN, Mirra P, et al. (2015) Regulatory $\mathrm{T}$ cells, inflammation, and endoplasmic reticulum stress in women with defective endometrial receptivity. Fertil Steril 103(6): 1579- 1586

10. Pattinaja DA, Spaanderman ME, Ghossein-Doha C, van Golde RJ (2015) Repeated implantation failure relates to circulatory abnormalities. Fertility and Sterility 104(3): e338.

11. Hasegawa E, Ito H, Hasegawa F, Hatano K, Kazuka M, et al. (2012) Expression of leukemia inhibitory factor in the endometrium in abnormal uterine cavities during the implantation window. Fertility and Sterility 97(4): 953-958.

12. Ozgu Erdinc AS, Yilmaz N, Candemir Z, Yilmaz S, Erkaya S (2013) Factor V H1299R (HR2) heterozygosity: a risk factor for recurrent implantation failure. Fertility and Sterility 100(3): S192.

13. Sugiura OM, Aoki K, Katano K, Ozaki Y, Suzumori K (2001) Factor XII but not protein $\mathrm{C}$, protein $\mathrm{S}$, antithrombin III, or factor XIII is a predictor of recurrent miscarriage. Fertility and Sterility 75(5): 916-919.

14. Sauer R, Roussev R, Jeyendran RS, Coulam CB (2009) Prevalence of antiphospholipid antibodies among women experiencing unexplained infertility and recurrent implantation failure. Fertil Steril 93(7): 24412443.

15. Pagidas K, Ying Y, Trimarchi J, Rick J Hackett, David L Keefe (2003) Frequency of aneuploidy among women with poor prognosis and recurrent implantation failure. Fertility and Sterility 80: 58.

16. Pagidas K, Ying Y, Keefe D (2004) Predictive value of repeated IVF-ET cycles with preimplantation genetic diagnosis for aneuploidy screening of embryos among women with recurrent implantation failure. Fertility and Sterility 82(Suppl 2): S36-S37.

\section{Your next submission with Juniper Publishers will reach you the below assets}

- Quality Editorial service

- Swift Peer Review

- Reprints availability

- E-prints Service

- Manuscript Podcast for convenient understanding

- Global attainment for your research

- Manuscript accessibility in different formats

( Pdf, E-pub, Full Text, Audio)

- Unceasing customer service

Track the below URL for one-step submission https://juniperpublishers.com/online-submission.php 